\title{
Controlling passive smoking through legislation in Ireland: an attack on civil liberty or good public health policy?
}

\author{
W.T. McNicholas
}

On March 29, 2004, comprehensive legislation was enacted in Ireland banning all forms of smoking in the workplace. This legislation was designed to prevent any worker being subjected to passive smoking and represented the first legislation of its kind in Europe. While broadly similar legislation is in place in parts of the USA, particularly in New York and California, the Irish legislation represented the first national legislation banning smoking in the workplace. Similar legislation has followed in Norway, and is likely to be introduced shortly in several other European countries.

The Irish legislation represents the culmination of efforts on the part of the national government and health authorities, dating back several decades, to reduce tobacco consumption. Successive legislation and regulations from the 1970s onwards prohibited tobacco advertising on radio and TV, and limited advertising in the print media. Taxes on tobacco products were maintained among the highest in Europe and discount selling was prohibited. Furthermore, spending on advertising and promotion by tobacco companies was strictly regulated.

Education programmes were also developed by the Health Promotion Unit of the Irish Department of Health to promote voluntary smoking cessation, and a voluntary ban on smoking in the workplace was developed in conjunction with major trade union and employer organisations. Organisations such as the Irish Heart Foundation, Irish Cancer Society, Irish Thoracic Society, and Action on Smoking and Health (ASH) were actively involved in lobbying efforts and education programmes aimed at reducing the level of tobacco consumption.

The measures described above had considerable success in that the prevalence of smoking in Ireland fell from $45 \%$ in the mid 1970 s to below $30 \%$ in the mid 1990s. However, smokingrelated diseases remained highly prevalent and international statistics demonstrate that Ireland has one of the highest mortality rates in Europe from ischaemic heart disease. Furthermore, the European Lung White Book [1], produced in 2003 by the European Respiratory Society and European Lung Foundation, demonstrates that Ireland has the highest mortality rate in Europe from lung disease. The evidence for a direct association of passive smoking with disease and death is now very strong, both in general [2], and specifically related to respiratory disease [3-7], ischaemic heart disease [8-11] and cancer [12-14]. There is also good evidence of specific molecular mechanisms involved in these relationships [15-17].

The present Irish legislation banning smoking in the workplace has its direct origins in 1999, when the Parliamentary Committee on Health undertook a detailed examination of the adverse health consequences of smoking. This initiative led to the establishment of the Office of Tobacco Control, and, in 2002, legislation was introduced that gave the Minister

Correspondence: W.T. McNicholas, President, European Respiratory Society, Dept of Respiratory Medicine, St. Vincent's University Hospital, Elm Park, Dublin 4, Ireland. Fax: 353 12697949. E-mail: walter.mcnicholas@ucd.ie for Health the powers to ban smoking in the workplace. In early 2003, the Office of Tobacco Control, together with the Health and Safety Authority, presented a report on the adverse health effects of passive smoking, which provided a strong political impetus for a formal ban on smoking in enclosed workplaces. While the scientific evidence of these adverse effects is quite clear, this report provided the evidence in a format that had the maximum public and (by extension) political impact. At the time of the report's release, the Minister for Health (and Children), Mr Micheál Martin, announced his intention to introduce a ban on smoking in the workplace, to come into effect in January 2004.

This announcement was strongly supported by the various political parties and also by the trade union movement. Furthermore, public opinion polls revealed that a large majority of the population supported the proposed ban. In fact, repeated polls throughout 2003 showed a consistent majority in the region of $70 \%$ of the population supporting a ban on smoking in the workplace. Surprisingly, a large proportion of current smokers also supported the ban and expressed the view that such a ban would make it easier to quit smoking. However, a vigorous campaign was launched by vested interests in an effort to block the introduction of the smoking ban and, in particular, to block the introduction of a total ban on smoking in pubs and restaurants. Since pubs and restaurants are places of employment, the ban would also include these venues. An alliance of interests came together under the banner of the "Irish Hospitality Industry Alliance" (IHIA) to co-ordinate a campaign of opposition, and a variety of arguments were put forward ranging from interference with civil liberty, catastrophic economic consequences and interference with the social fabric of society. The IHIA also argued that the ban would be unenforceable.

The opposition to the ban particularly focussed on the impact on Irish Pubs because of their special place in Irish Society. It is longstanding custom in Ireland for people to meet socially in the local pub and Irish pubs are viewed as venues for social interaction rather than places exclusively designed for the consumption of alcohol products. The Irish pub is well recognised as a special place throughout the world to the extent that the product has been packaged for export and most cities throughout the world now have replica "Irish Pubs" that attempt to mimic the atmosphere of the "genuine article". The IHIA argued that a total ban on smoking in pubs would gravely undermine business on the basis that people would seek other venues to meet if one or more of the group were smokers. Furthermore, the argument was put forward that the tourist industry, which is a major source of employment in Ireland, would be seriously damaged by such a ban. While the tobacco industry did not actively participate in the campaign, there was a strong suspicion that the industry was helping to drive the opposition behind the scenes. There is a history of active involvement by the tobacco industry in efforts to discredit relationships between passive smoking and disease [18]. 
The campaign of opposition continued throughout 2003 but, to his great credit, the Irish Minister, Mr Martin, held firm. Professional organisations, including the European Respiratory Society, expressed strong support for the introduction of the ban and the trade union movement also consistently expressed support. This latter support was very important because of the arguments put forward by the IHIA that tens of thousands of jobs would be lost in the hospitality industry following the introduction of a smoking ban. Some exemptions were eventually allowed for places that could legally be regarded as a person's temporary home, such as hotel bedrooms and prison cells, and the ban was postponed from its initial implementation date of January 1, 2004, partly because of the debate over exemptions, but also because of the legal requirement to provide a minimum period of notice to the European Union. However, despite the opposition, the ban was introduced on March 29th, 2004.

What has been the outcome of the Irish ban? Compliance has been excellent, being in excess of $95 \%$ in pubs and restaurants throughout the country. Despite the prophets of doom and gloom, Irish pubs are not closing down in droves. In fact, several pubs have been sold since the introduction of the ban for record amounts. While it is too early to assess the actual impact on business, early figures indicate that sales of alcohol products in pubs throughout Ireland have fallen by about $15 \%$. However, there is some evidence that food sales have increased, reflecting a shift in the general public's attitude towards the pub being regarded as a suitable place to have a meal rather than simply a venue to socialise around alcohol. Those who have been exposed to the "smoky pub" in the past will easily recognise the improvement in the pub environment as a suitable place to eat food. However, an unexpected consequence of the ban has been that, in some poorly ventilated pubs, the smell of cigarette smoke has now been replaced by other unpleasant odours!

Irish pubs are now focussing on measures to limit the effects of the ban on their business. The sale of outdoor patio heaters has rocketed in Ireland this year as pubs develop outdoor areas where smoking customers can congregate to "have a smoke". There is some preliminary evidence to suggest that smoking levels have reduced and surveys clearly indicate that smokers smoke less now when out for a night in the pub since they must leave the company they are in and go outdoors to smoke. Whether the ban will substantially reduce the overall smoking levels in Ireland remains to be seen, but there is good reason to believe that this will be the case.

The Irish ban has received considerable media attention abroad and the positive Irish experience has undoubtedly provided encouragement for other national governments to introduce similar bans. However, the response in some countries has been ambivalent, particularly the UK. Rather unflattering cartoons have appeared in some British newspapers depicting Irish "Tobacco Police" and introducing the notion that a ban on smoking in the workplace would represent an unacceptable interference with civil liberty. Furthermore, a recent remark by the UK Health Secretary suggested that a ban similar to the Irish one should not be introduced in the UK since it would deny people on low incomes one of the few pleasures available to them! This position appears a remarkable perversion of the real consequences of tobacco consumption, particularly by the senior politician responsible for dealing with the health consequences of smoking. However, more recent media comment in the UK has been generally supportive of a workplace smoking ban.

Overall, the early results of the Irish ban have been strongly positive, in that compliance is almost universal and pubs have become a much healthier environment for the public to socialise in. Tourism figures are higher this year compared to previous years, and the Irish model is viewed positively by most commentators in Ireland and abroad. Previous reference has been made to the Irish Pub as an export phenomenon. Perhaps this model should now be refined to view the Irish Pub abroad as a smoke-free environment. Now, there's a thought!

\section{References}

1. European Respiratory Society/European Lung Foundation. The European Lung White Book. Loddenkemper R, Gibson GJ, Sibille Y, eds. Sheffield, UK, ERSJ, 2003; pp. 1-182.

2. Sandler DP, Comstock GW, Helsing KJ, Shore DL. Deaths from all causes in non-smokers who lived with smokers. $\mathrm{Am}$ J Public Health 1989; 79: 163-167.

3. Hole DJ, Gillis CR, Chopra C, Hawthorne VM. Passive smoking and cardiorespiratory health in a general population in the west of Scotland. BMJ 1989; 299: 423-427.

4. DiFranza JR, Aligne CA, Weitzman M. Prenatal and postnatal environmental tobacco smoke exposure and children's health. Pediatrics 2004; 113: Suppl. 4, 1007-1015.

5. Svanes C, Omenaas E, Jarvis D, Chinn S, Gulsvik A, Burney P. Parental smoking in childhood and adult obstructive lung disease: results from the European Community Respiratory Health Survey. Thorax 2004; 59: 295-302.

6. Sturm JJ, Yeatts K, Loomis D. Effects of tobacco smoke exposure on asthma prevalence and medical care use in North Carolina middle school children. Am J Public Health 2004; 94: 308-313.

7. Jaakkola MS, Piipari R, Jaakkola N, Jaakkola JJ. Environmental tobacco smoke and adult-onset asthma: a population-based incident case-control study. Am J Public Health 2003; 93: 2055-2060.

8. Sargent RP, Shepard RM, Glantz SA. Reduced incidence of admissions for myocardial infarction associated with public smoking ban: before and after study. BMJ 2004; 328: 977980.

9. Glantz SA, Parmley WW. Passive smoking and heart disease. Mechanisms and risk. JAMA 1995; 273: 1047-1053.

10. He J, Vupputuri S, Allen K, Prerost MR, Hughes J, Whelton PK. Passive smoking and the risk of coronary heart disease a meta-analysis of epidemiologic studies. N Engl J Med 1999; 340: 920-926.

11. Fichtenberg CM, Glantz SA. Association of the California Tobacco Control Program with declines in cigarette consumption and mortality from heart disease. $N$ Engl J Med 2000; 343: 1772-1777.

12. de Andrade M, Ebbert JO, Wampfler JA, et al. Environmental tobacco smoke exposure in women with lung cancer. Lung Cancer 2004; 43: 127-134.

13. Brennan P, Buffler PA, Reynolds P, et al. Secondhand smoke exposure in adulthood and risk of lung cancer among never smokers: a pooled analysis of two large studies. Int $J$ Cancer 2004; 109: 125-131.

14. Vineis P, Alavanja M, Buffler P, et al. Tobacco and cancer: recent epidemiological evidence. $J$ Natl Cancer Inst 2004; 96: 99-106.

15. Panagiotakos DB, Pitsavos C, Chrysohoou C, et al. Effect of exposure to secondhand smoke on markers of inflammation: the ATTICA study. Am J Med 2004; 116: 145-150.

16. Tsiara S, Elisaf M, Mikhailidis DP. Influence of smoking on predictors of vascular disease. Angiology 2003; 54: 507-530.

17. Zhu BQ, Heeschen C, Sievers RE, et al. Second hand smoke stimulates tumor angiogenesis and growth. Cancer Cell 2003; 4: 191-196.

18. Trotter L, Chapman S. "Conclusions about exposure to ETS and health that will be unhelpful to us": how the tobacco industry attempted to delay and discredit the 1997 Australian National Health and Medical Research Council report on passive smoking. Tob Control 2003; 12: Suppl. 3, 102-106. 